\title{
Madhubani Painting-Vibrant Folk Art of Mithila
}

\author{
Soma Ghosh \\ Librarian and Media Officer, Salar Jung Museum, Ministry of Culture, Government of India, Hyderabad, India \\ Email: somaghosh1133@gmail.com
}

How to cite this paper: Ghosh, S. (2020). Madhubani Painting-Vibrant Folk Art of Mithila. Art and Design Review, 8, 61-78. https://doi.org/10.4236/adr.2020.82005

Received: March 12, 2020

Accepted: April 17, 2020

Published: April 20, 2020

Copyright (c) 2020 by author(s) and Scientific Research Publishing Inc. This work is licensed under the Creative Commons Attribution International License (CC BY 4.0).

http://creativecommons.org/licenses/by/4.0/

\begin{abstract}
This article traces the historical journey of a unique art-form, that of the painting of walls, floor-spaces and on the medium of paper, of Madhubani painting, referring to the place from where it became famous from the region of Mithila in North Bihar. The land of its origin being India, the social and cultural context is also explored. The article aims to document the main artists in the field, who have given their lives in preserving this form of painting and been applauded by the Government of India for their efforts. The painting style has ancient origins and it has caught the eye of both Indians and foreign art enthusiasts. The different sources from which the colours are derived for use have also been noted. Now the art-form finds expression in walls of public places like railway stations, in addition to traditional spaces and during social events. There have been National Award winning artists and the art has made long journeys. The art has combined both the traditional and contemporary themes and been transferred to apparel, upholstery, tableware and sold as artwork for modern homes and interiors. Novel themes have found a place in the art to give it a new appeal. The artists who have made a contribution in revival and sustenance of the art have been listed, with their short biographies in the article, along with interesting illustrations of this vibrant, colourful and timeless art-form.
\end{abstract}

\section{Keywords}

Madhubani, Mithila, Wall Painting, Madhubani Painting, Mithila School of Painting, Aripana, Folk Painting of India

\section{Introduction: Madhubani Painting}

A very interesting news-item in 2017 was that artists have painted the walls of a railway station! The station is that of Madhubani, with an ancient art-form from the land of Mithila. Madhubani locates $190 \mathrm{~km}$ from Patna, the capital of Bihar 
in India. This art is popular in North Bihar and originally in some parts of Nepal. Though this art is now well known to the world, news items like this help refocus the world's attention to an ancient art form which originated in the land of Mithila to which Madhubani belongs. This art is mostly referred to as "Madhubani painting". Figure 1 shows women artists decorating the walls of the Madhubani railway station in Bihar. Figure 2 depicts a bright mural drawn at the station.

The Indian epic Ramayana is well known and Lord Rama is believed to have commissioned a painting during his wedding to Sita, daughter of King Janaka of

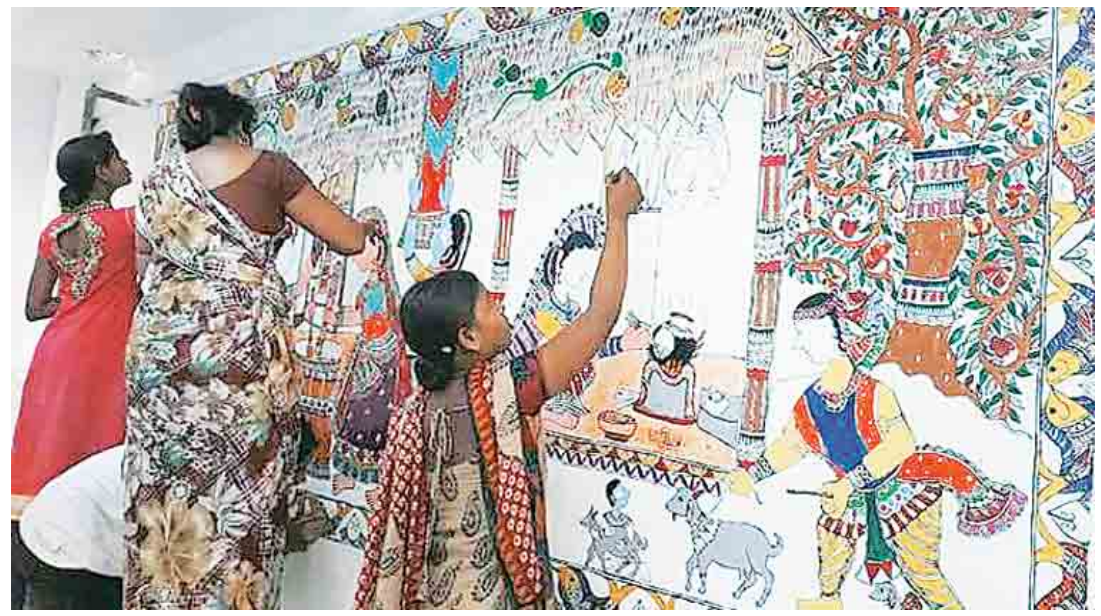

Figure 1. Artists at the Madhubani railway station, Bihar (Source: http://indianexpress.com/article/india/painting-the-town-in-madhubani-4997613/ (newspaper image) (accessed 12.03.2020)).

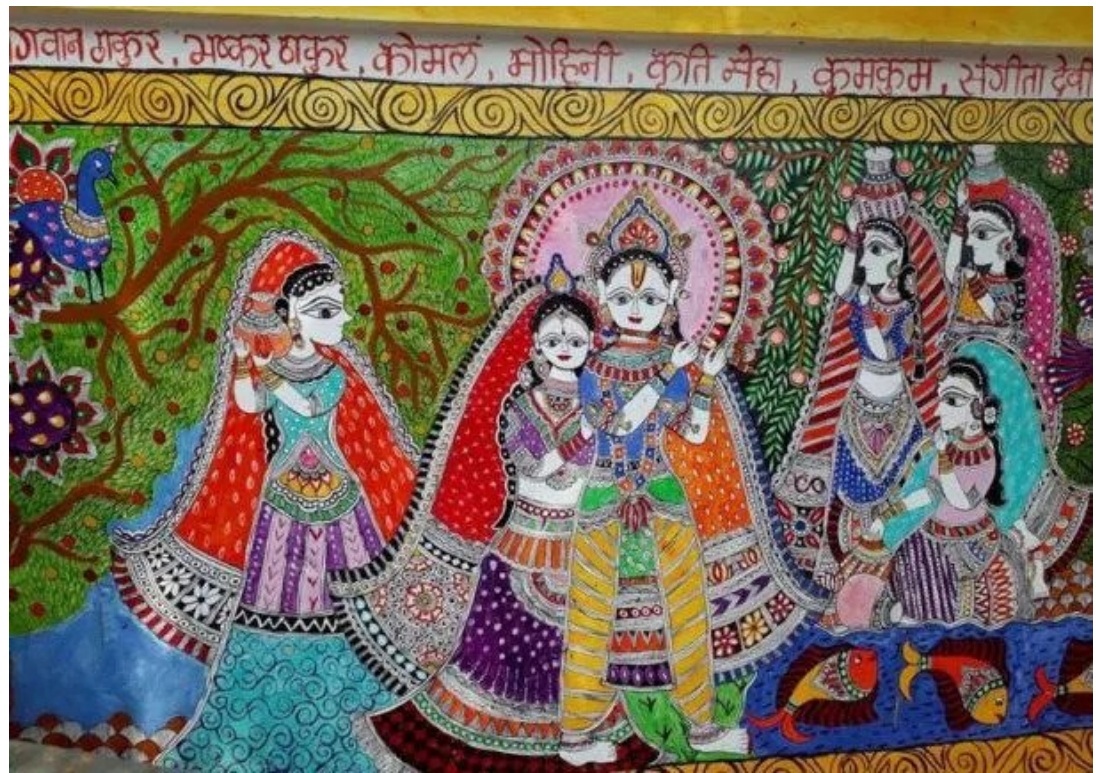

Figure 2. Mural, Madhubani Railway station, Bihar (Source: http://indianexpress.com/photos/lifestyle-gallery/mithila-artist-transforms-madhubani-rail way-station-with-traditional-madhubani-paintings-for-free-4930059/2/ (newspaper image) (accessed 12.03.2020)). 
Mithila to capture the event. The term Madhubani means forests of honey. Also it is a place in Mithila whose art form has become synonymous with liveliness and colour. In the present times, Madhubani is a market town and most of the painters work in villages like Jitwarpur, $3 \mathrm{~km}$ away. Mithila painting and Madhubani painting are interchangeably used, though the term Mithila art is an umbrella term which includes art on paper, apparel, pots, dishes, fans and other items both decorative and utilitarian. The journey of the art can be well understood by and trace its history and evolution over the years, including the techniques and colours used for the paintings. Also the contributions of the artists who were initially anonymous housewives and later came to their own by sheer merit and Government and other support, can be studied to get the total story of this art form.

\section{Historical Backdrop: Echoes from the Past}

Regarded as the Mithila School of painting, it originated mostly in North Bihar and depicts religious stories in painting. It is called commonly called Madhubani painting which is done mostly by women (Anand, 1984). This vibrant art of Madhubani art is being created since many centuries in some parts of Bihar in India; in fact there is no concrete evidence as to when it actually began. The art was first highlighted as "Maithil" painting (Archer, 1949), a British Civil Servant in 1934 who went there after an earthquake. He also explored Purnea, Darbhanga and adjoining areas when he got a chance to go to the area again in 1940 as Provincial Census Superintendent. The findings came as an article in Marg-a magazine of arts in 1949. A research on the historiography on Madhubani in (Neel, 2010) mentions Pupul Jayakar who as Chairperson of Handloom Handicraft Export Corporation took a lot of interest in the painting style while initiating a drought relief programme and even wrote about it in 1970s and early 1980s. Madhubani got noticed when the painting shifted to the medium of paper in addition to walls by women from villages around Madhubani, like Rashidpur, Leheriagunj and Harinagar. The art started reaching the middle class and art enthusiasts. The art got national recognition when artists like Jagadamba Devi, Sita Devi were given National awards by the President of India. This art form is well-liked by the European and Canadian people among others. The exhibition Expo-70 in Japan and Asia-72 further established this art form ensuring sales of the paintings, which were made on paper, instead of the regular floor or walls of the villages. Neel Rekha in her research mentions that there were indirect references to the art in regional texts from the $14^{\text {th }}$ century onwards; while trying to explore its transformation from folk art to a fine art. The art has become more visible and the elite of Bihar has responded well to the popularity of the art form and looked at it as an expression of their cultural heritage. Further she notes that the award winning artists are well travelled and exhibitions have been held in France, Germany and the USA. These women also represented a kind of "women power" in predominantly patriarchal Bihar, though men are doing paintings 
too and making a mark Some foreign scholars have studied the art like Erika Moser, a German folklorist, Yves Vequaud and a French journalist who encouraged the other caste women to reflect their day to day life in their paintings. A Mithila Museum has been established in Japan by Tokio Hasegawa, a Japanese visitor to Madhubani. Nowadays one gets to see the art form on saris, trains, picture galleries, walls of railway stations and private drawing rooms. However, as noted, Madhubani painting needs to be constantly protected from the effects of commercialization (Thakur, 1981). But innovation is inevitable which can be taken as either dilution of the art or as some freshness being infused to a traditional art form.

To step back in time it is mentionable that Mithila is an ancient land north of the Ganges (Thakur, 1981). Madhubani is the heart of Mithila. There are extant remains of cities of ancient rulers at Mithila. It is the land of the ancient Maithilas bounded on the North by the Himalayas, on east by river Kausiki, south by the Ganges and west by the Gandaki. The land is around 25,000 square miles; parts of it in Nepal. Mithila has been the land of the Janaks. Vaishali was a renowned Buddhist and Jaina centre. Many geniuses have walked this land; Kapila; founder of Samkhya philosophy, Gautama Aksapada (author of Nyaya-sastra), Jaimini, founder of the Mimamsa school. The area has been with the Vaidehas, the Licchavis, the Magadhans, Mauryas, Guptas and Karnata dynasty. It came under Mohammedan rule in 1324. After that the land was ruled by the Oinavara dynasty for about two centuries. Mithila is also known as Tirhut or Tirabhukti. The Mughals subdued this dynasty; however the Khandavala dynasty was founded (1556-1952) when Mughal Emperor Akbar gave Tirhut to its founder Mahesa Thakura.

Mithila has been a Buddhist and Jaina stronghold too. Tirthankaras were born here and Lord Buddha had come to Vaishali. The land of Mithila has been culturally very rich. Architecture, sculpture, painting, music was very popular among the kings and the people. Sculptures in bronze, stone and ivory have been found in Mithila. Images of all deities have been found. Folk arts were also well developed. Silver miniature objects and carved wooden images were made by artisans of Mithila. Painting on walls has been an intrinsic part of life done mostly by women as already mentioned. On religious and social occasions like vratas, the women decorate the walls with lively artwork which captivates the mind and soul of the onlooker. Mithila painting is categorised under folk art. The artists paint on walls, canvas and on the floor; bhitti, pata and aripana respectively.

Folk art has mostly been started for utility purposes or for rituals. Mostly the depictions are religious in nature. In Mithila, painting was mostly done on the wall or the floor since yore. The wall paintings are also called bhitti-shobha. In southern Bihar (now Jharkhand), it is called urehana. Mithila art in its sophisticated form is practiced by Brahmin and Kayastha caste women. The other castes worked on utility items for use in their homes. There seemed to be refinement in the work of the "kulina" women (the Brahmins and Kayasthas), traceable to the 
patterns made during Vedic sacrifices; the components of samskaras and vratas being very prominent. Aripanas are created according to the samskara and the patterns originated between 1097 A.D. to 1550 A.D. under the Karnatas and the Oinavaras and were carried on during the Khandavalas, also called Darbhanga raj upto recent times.

The art of aripana or drawings on the floor is a legacy, handed down through generations. The aripana is an important part of occasions and during festivals. The women get to learn and execute the aripanas as they learn it as a part of growing up, naturally. The main lady who does the drawing is called the aripana denihari.

Aripanas relating to worship of different Gods and Goddesses are made during different pujas and rituals. The art is taught by mother to daughter and the painting tradition is continued. The aripanas are done in different ways; mandala drawings and the tantric designs, vrata mandalas. Aripana or alepana is derived from the word alimpana which means the art of drawing ali (wall) and that these drawings made for vratas are believed to act as a channel for invoking nature's energies. These aripanas as line drawings on the ground are done during ceremonies (Thakur, 1981). It figures among the 64 arts mentioned in the ancient treatise grihasutra. They are made in the courtyard, at entrance of the house among other places. Aripanas are traditionally made with a mix of rice powder and water called pithara. The colours red, green, yellow and black are also used along with vermillion (sindoora). Various deities of Hinduism like Shiva-Parvati, Radha-Krishna, Vishnu-Lakshmi are depicted.

The aripanas are of different types: The sarvatobhadra is a diagram drawn during Tulasi puja, Durga puja and in vrata, usually done on an initial format of one, three, five, seven or nine dots of vermillion as two triangles, one pointing to the sky and one to the earth. This motif is believed to be the source of all mandalas in vrata puja and the yantras used in the puja have also evolved from it; drawn near the Tulasi plant in the courtyard of the Brahmin and Kayastha homes of the Mithila region. The sarvatobhadra used to be drawn during Vedic sacrifices. Aripanas symbolises the presence of Shakti. The aripanas are closely related to Tantric cults. The astadala, another type of aripana is an 8 petalled lotus drawn for the Durga Puja. This is also used for the worship of Lord Vishnu. The eight petals symbolises the eight siddhis. On the eight petals are depicted the sankha (conch), khadga (sword), damaru (drum), chakra (disc), pasa (mace), sala (spear), padma (lotus) and half moon with dot (bindu-yukta ardhachandra). During worship of Lord Vishnu, his various forms are depicted. The other aripanas include saddala aripana, swastika aripana, dasapata aripana and madhusravani aripana. Aripana is a ceremonial art and done on occasions like the thread ceremony, marriage, Batsartli (worship of Bat tree (banyan), a symbol of long life. Also made during Nag-panchami; the worship of snakes, Satyanarayana puja as well.

Other castes, who have been called Harijans by Mahatma Gandhi and now called "Dalits", from castes like Chamar, Dusadh and Ahirs, have taken up 
painting which depict their heroes like Rahu, Salhesa (actually Vedic God Indra) and Govinda. They also made narrations of their daily life and ritual practices. This art developed at Jitwapur, $3 \mathrm{~km}$ from Madhubani town and also got accepted by art lovers. As already stated, men joined painting activity and socially relevant themes too found a place (Neel, 2010).

\section{Madhubani Murals: The Writing on the Wall}

The folk paintings of Mithila region are made on walls; the murals are what is commonly understood as Madhubani painting. These paintings are made on the walls of houses at Madhubani at Jitwarpur, Ranti, Darbhanga, Saharsa and Purnea. In 1967-68 this painting form got a fillip by the efforts of Sri Lalit Narayan Mishra, Foreign Trade Minister, Upendrra Maharathi and Bhaskar Kulkarni, artists (Thakur, 1981). It is a feminine art mostly made by women who are housewives. Some important artists have been Maha Savitri Devi of Ranti, Sita Devi of Jitwarpur, Baua Devi Jha, Jagadamba Devi and Mahasundari Devi who have become world famous. Figure 3 is an iconic painting by artist Sita Devi depicting Radha-Krishna along with a "gopi" or cowherd girl, a popular theme.

The style of painting varies from village to village. The ones made by the upper castes, Brahmin and Kayasthas have a unique quality of space. There are small figures and large figures juxtaposed with each other. The symbols used in the painting resemble those on pottery found at Harappa, an important Indus valley civilisation site. Folklore has it that women of King Janaka's household used to paint on walls. Urmila (Lakhsmana's wife) made his image on a wall and worshipped it when he went to the forest with his brother Lord Rama and Sitadevi during his exile. This is from the Indian epic Ramayana. The Sonars, Ahir

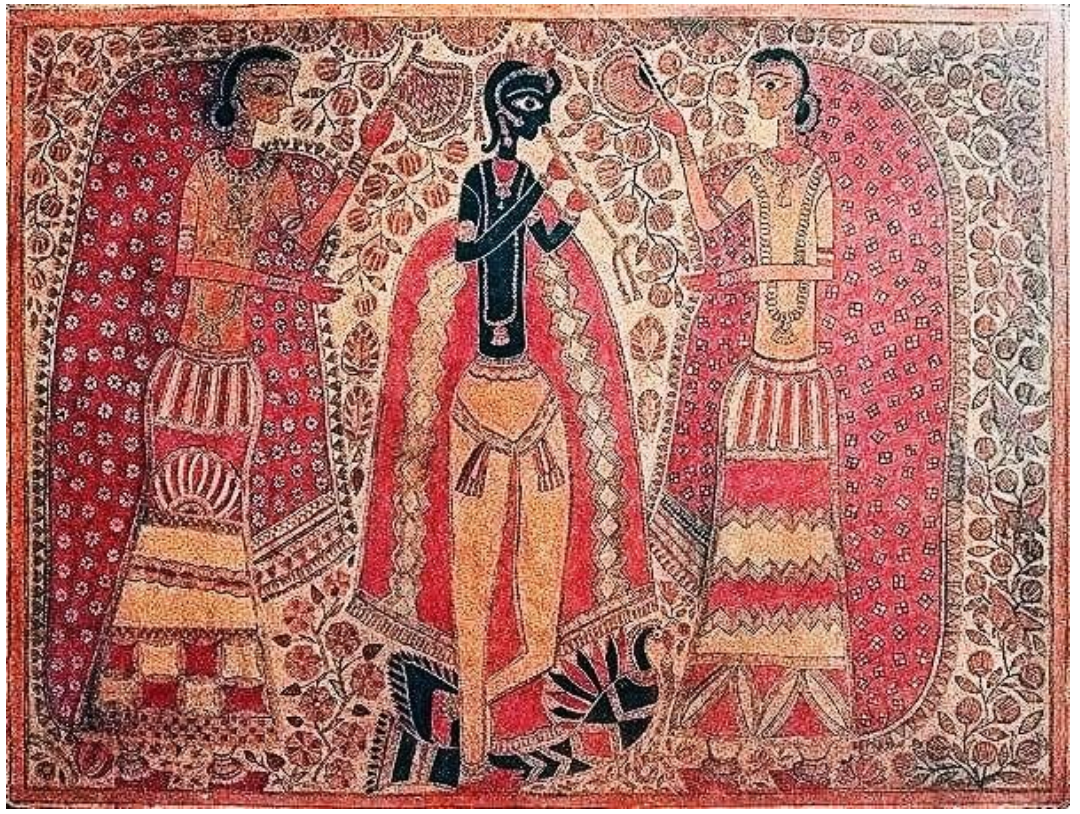

Figure 3. Radha-Krishna, Madhubani painting (Source: Wikimedia Commons, accessed 12.03.2020). 
and Dusadhs also do paintings but only isolated households got involved but with time more have come to the field.

A girl was given the designs in paper form when she gets married so that she can use in her new home, and also introduce new designs. The area of Mithila has been under Brahminical domination which has had an influence on all aspects of life in Mithila. The process of painting has given a medium of expression to the women. These women are natural artists and don't really follow any norms. Though some artists are well known many faded away after creating awesome art.

The wall paintings in Mithila homes are mostly executed on the wall of three places. The Ghosain-ba-ghara, room of the family deity, the Kohabara ghara; room for newly-weds and kohabara ghara ka koniyan, the verandah outside the kohabara. The kohabara room has paintings mostly of mythological stories and legends made of red coloured mineral pigment, gairika (Thakur, 1981). Figure 4 is an example of a kohabara painting by artist Sita Devi. Not all paintings are narrative in nature, some depict nature; plants and animals. Figure 5 shows a stylized peacock, the national bird of India. There are themes of the paintings like the Harisauna piya ka chitra done with vermillion depicting the life of two girls. The Ghosain ghara ka chitra is also a type of wall painting. The Sarovarachitra is a family pool and depicts fish, turtles etc. Inside the bridal chamber nayana yoginis with articles which they carry on their heads is painted in four corners. The verandah outside has paintings of rural scenes of the Mithila region. Figure 6 depicts the Mahavidyas, a concept from Indian mythology; which refers to the group of ten aspects of "Adi Parashakti", all forms of Goddess Parvati in Hinduism. Sometimes the paintings are made on paper, pots, fans and earthen-dishes. The art from lacks symmetry, animals are depicted to symbolize

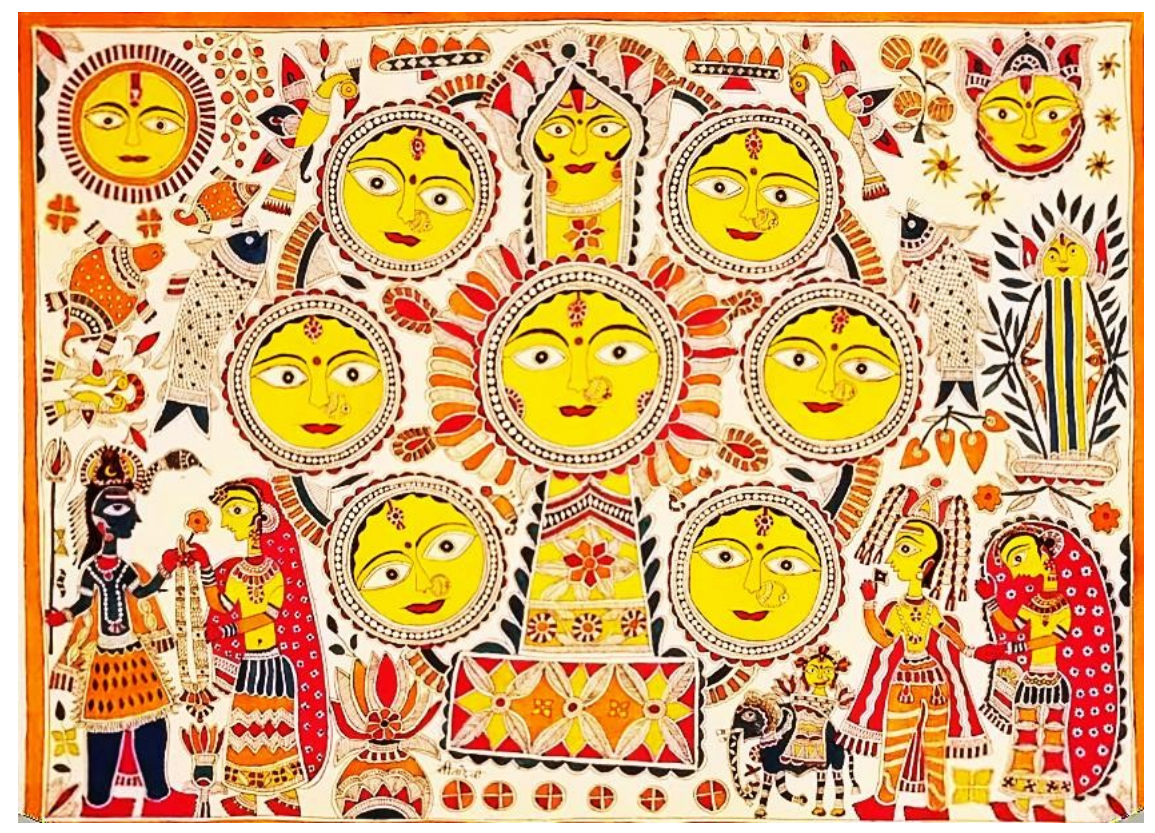

Figure 4. Kohabara, Mithila painting (Source: Wikimedia Commons, accessed 12.03.2020). 


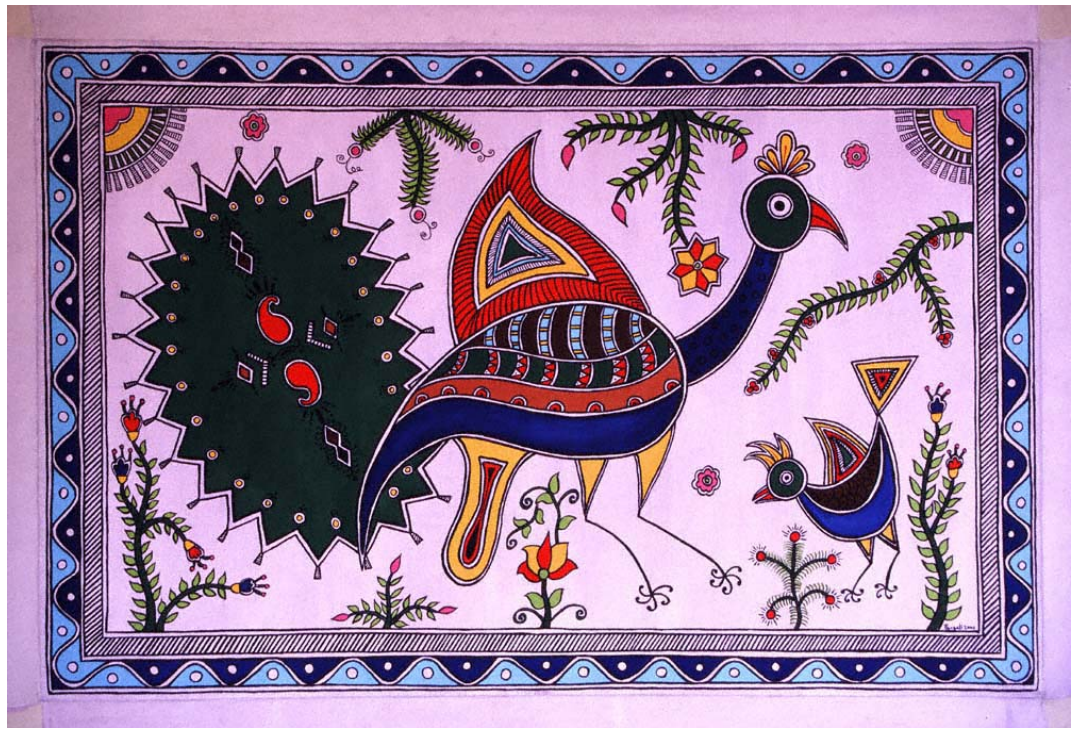

Figure 5. Peacock depiction, Madhubani painting (Source: Wikimedia Commons accessed 12.03.2020).

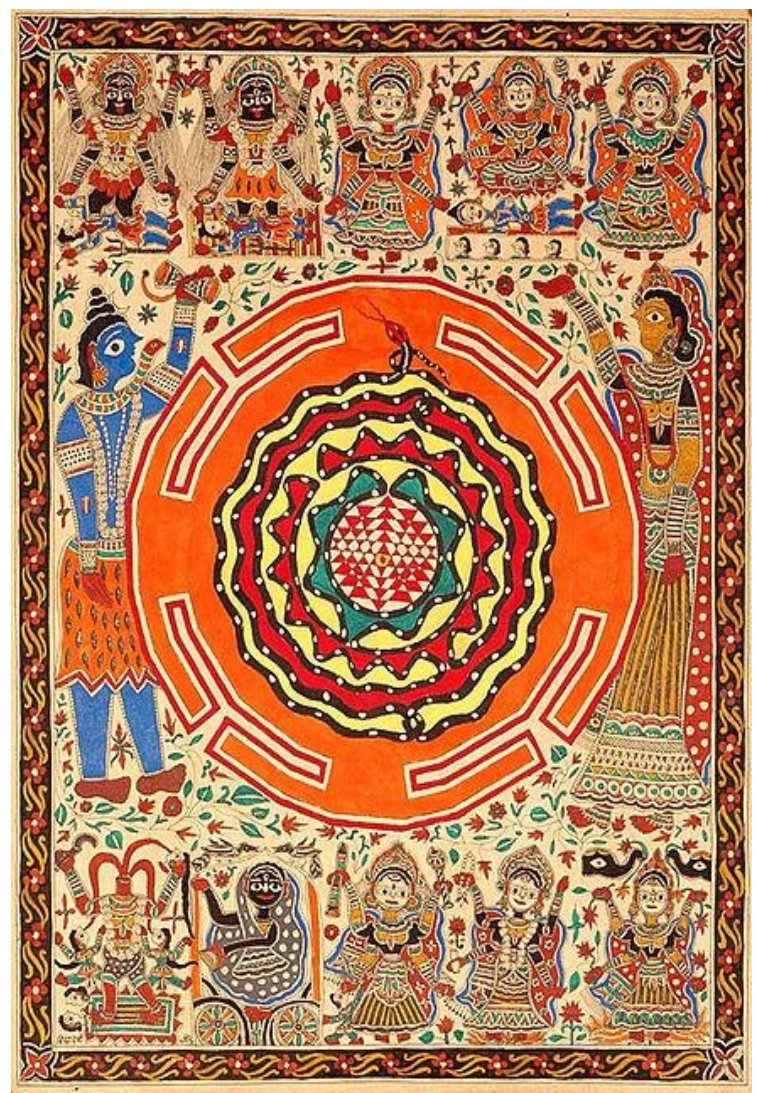

Figure 6. Mahavidyas, mythological Madhubani painting, toyin adepoju. CC BY-SA 3.0 https://creativecommons.org/licenses/by-sa/3.0, via Wikimedia Commons (accessed 12.03.2020).

energy and character. The turtle symbolizes union, fishes depict fertility, lotus and bamboo represent the genders, female and male respectively. All this is translated sometimes into strange figures, with a fantastic dimension with float- 
ing images (Tiwari, 2018). The net result is one of brightness and a burst of energy.

\section{Techniques of Painting: A Labour of Love}

The wall surfaces are prepared by plastering with cow dung or first white-washed on which paintings are made. The paints were previously prepared but now they are procured from villages from the market town of Madhubani, Purnea with the supply coming from Kolkata. The colours used are gulabi, nila, sindura, sugapankhi (green). Originally black was made from burnt barley seeds, yellow from turmeric, or chuna (lime) mixed with milk from banyan leaf, orange from palash flower, red from the juice of the kusuma flower and green from bel leaves. Paintings of the Kayastha families have brown, yellow-ochre, turmeric and myrobalan (harada), madder red and black colours which are bought in modern times, mixed with goats milk. White colour can be got by mixing of rice powder in water. Colours used to create black is from soot, light brown is derived by mixing cow-dung and gum in fresh water. Pipalbark yields pink when dried and boiled in water. Blue colour is obtained from berries of an herb called sikkar. Dark green is from the Siam creeper and parrot green from the sepals of gulmohar. Red can also be derived from clay, yellow from pollen (Thakur, 1981), but nowadays other organic and mineral colours are being used. Figure 7 is a Madhubani painting housed at The Asia and Pacific Museum, Warsaw by artist Mudrika Devi.

Madhubani paintings have many colour settings: deep red, green, blue, black, light yellow and pink. Red is dominant in many paintings. A bamboo twig is used for drawing outlines. For filling colour pihua, a small piece of cloth tied to a twig is used. Women gather together and make the painting. A leader among

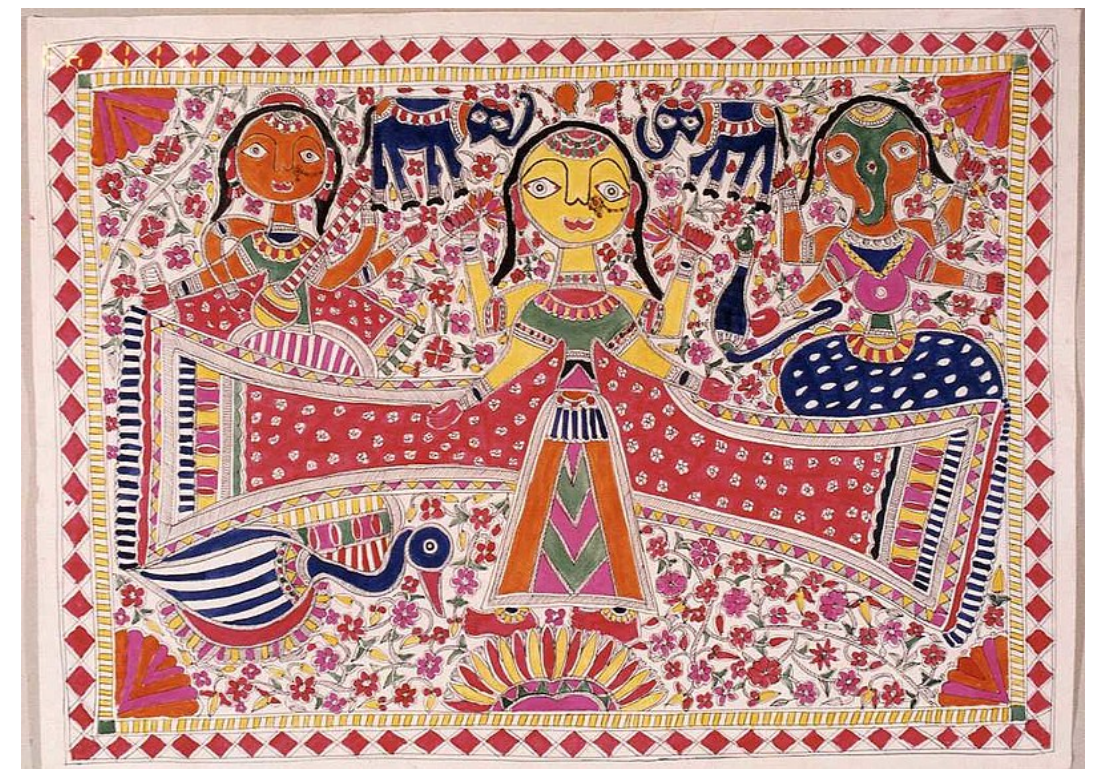

Figure 7. Lakshmi, Ganesha and Saraswati, Madhubani painting (Source: Asia and Pacific Museum in Warsaw by Mudrika Devi). 
them draws the composition and others fill in the colour. Younger girls assist the older women. Kayastha families keep paper notes of the artwork, to be made during ceremonies. It is even shared with the same caste from different villages. The styles get repeated but with variations, though the idioms remain the same. Now synthetic colours are also being used as seen in Figure 8 for modern creations, since organic dyes take long to prepare.

\section{Theme of the Paintings: Varied and Timeless}

The favourite deity of the Brahmins and Kayasthas is Goddess Durga. Goddess Kali is an important deity in Tantrik rituals and tantra has had an important effect in the making of Aripana and wall paintings. The major motifs used depict flora, fauna, mostly natural life, also Gods, goddesses, lion, fish, parrot, turtle, bamboo, lotus, creepers, "swastika" among others. These forms are interchangeably used as per the ritual. Events like the thread ceremony, initial wedding formalities, final wedding rites, the renovation of shrines, all demand paintings. Paintings are made for both beautification and sanctification of the courtyard and threshold. Kohabara paintings augment well for the marriage. Figure 9 depicts a painting done for the kohabara. The kadamba tree, sun, flowers, peacocks, moon, palanquin, tortoise, fish are all depicted. Bhitti chitra or wall paintings are drawn on auspicious occasions. Symbols used in Madhubani painting have their

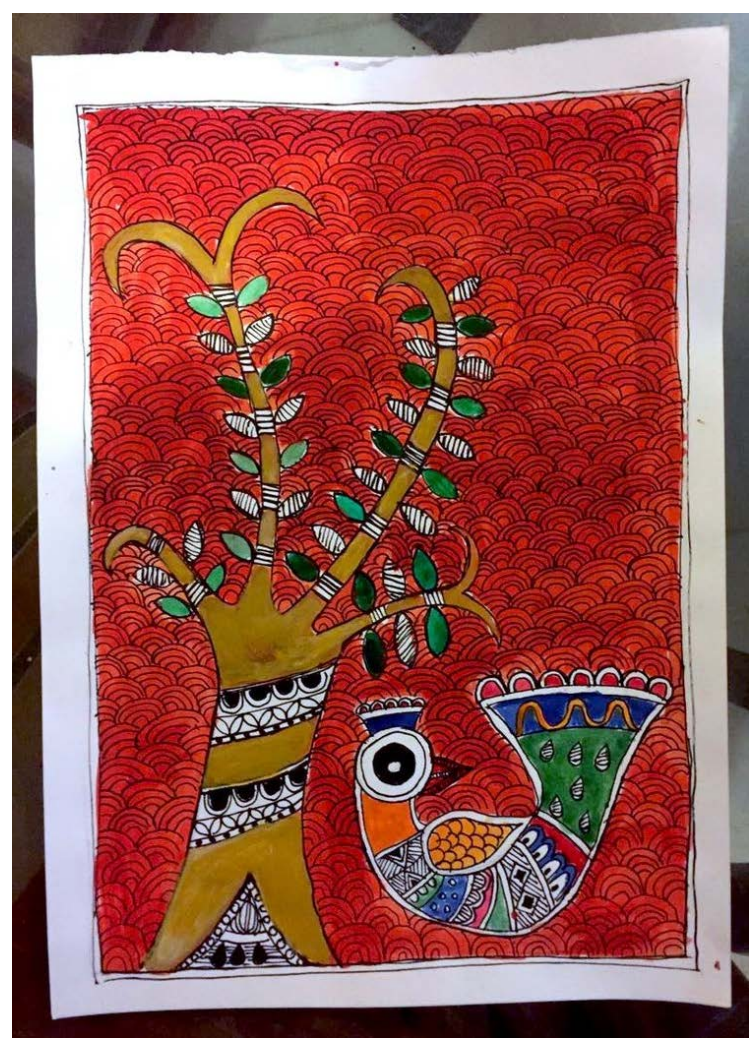

Figure 8. Madhubani painting, modern art using synthetic colours. Theshruview, CC BY-SA 4.0, https://creativecommons.org/licenses/by-sa/4.0, via Wikimedia Commons (accessed 12.03.2020). 


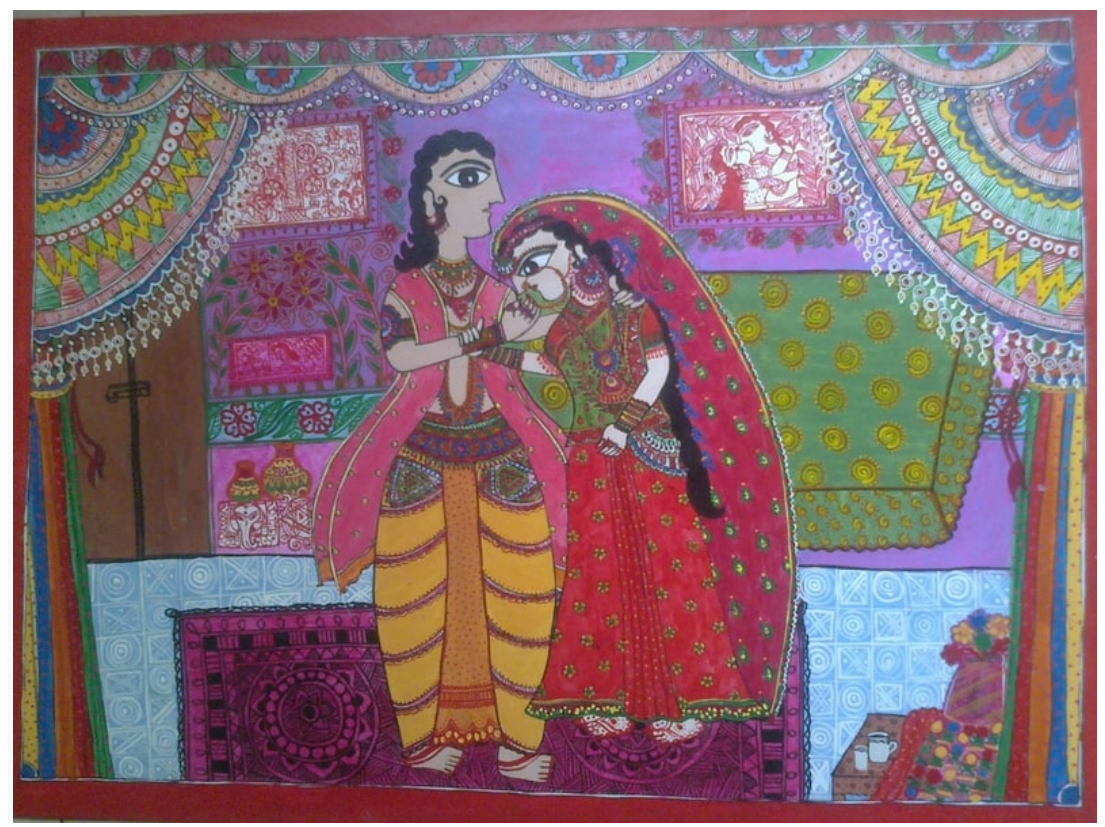

Figure 9. Kohabara theme, Madhubani painting. (Source: Wikimedia Commons, accessed 12.03.2020).

own significance. Elephant, palanquin denote royalty. Sun and moon represent long life. Goose and peacock are symbols of welfare and calmness (Thakur, 1981). Lotus denotes good luck and the feminine, the bamboo denotes future progeny and the male gender.

During the thread ceremony or upanayana, Gods and Goddesses, sun and moon are depicted. Figure 10 depicts Goddess Durga in a painting. During weddings again sun and moon, a bamboo tree, a circle of lotuses, parrots, fish etc. are drawn. The lotus is female and the bamboo is taken as a male symbol. The parrots, turtles and fish are significant too. Parrots symbolise the love birds, turtles signify water and union of lovers. Fishes are symbols of fertility. Sun and moon represent life preserving qualities.

The human forms are linear and abstract. The Brahmin paintings have bright reds and yellows. They depict a particular subject matter. A lot of red is used and themes from Bhagavata Purana are commonly used. Scenes from the life of Lord Krishna, a favourite God of India, are seen. Other themes include the elephant, fish, tortoise, stylised tigers, floral forms etc. The paintings don't follow any logical patterns. Figures of animals, birds could be drawn to fill white spaces.

As already noted the Dalit paintings use themes of stories of their own heroes and have a quality by themselves. These paintings can be understood as a kind of self assertion. Madhubani art could be transforming into a fine art as per David Szanton, President, Ethnic Arts Association, U S A (founded in 1980) who writes about and curates exhibitions believes; owing to the combination of tradition and individual expression as seen in the works of Ganga Devi (Jain, 1997). Further, David Szanton opines that Madhubani painting should be referred to more as Mithila painting which would be a more inclusive term with its new styles and 


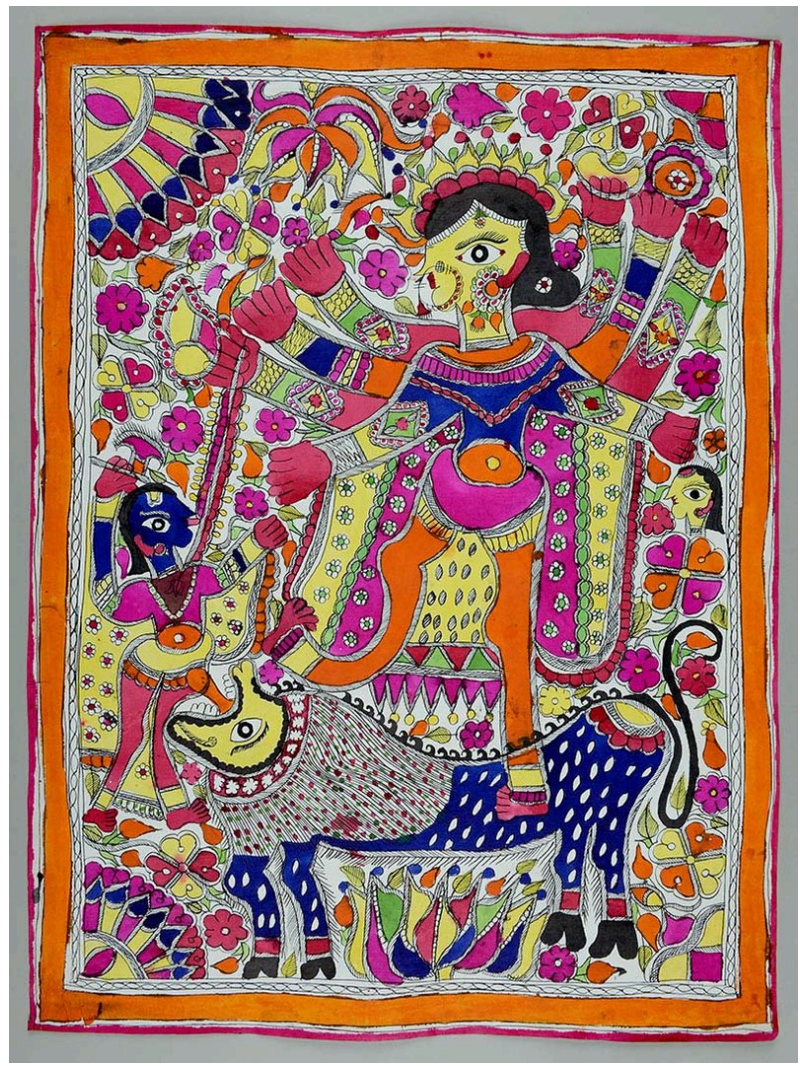

Figure 10. Goddess Durga, Madhubani painting (Source: Asia and Pacific Museum in Warsaw by Ijnila Devi).

lack of Western influence (Neel, 2010). However another school of thought will always feel that the Kohabara version is the authentic Madhubani and commercialistaion of the form is destroying the tradition.

In spite of all this, this art is evolving with the times. It is getting depicted on saris, t-shirts, paper stands, bags, home décor and apparel like dupattas and palazzos in addition to public places and traditional surfaces.

\section{Artists of Madhubani: Inner World, Outer World}

\subsection{Sita Devi}

She is a celebrated artist of Madhubani art. She brought the art to the outside world from the rural homes. She was born in 1914. She is from Jitwarpur village at Madhubani in Bihar. She has got conferred with the State award in 1969, National award in 1975 and the Padma Shri in 1981. She got the Bihar Ratna Samman in 1984. She has encouraged the art among 1000 people in her village. Her art was sought after by many, including Presidents and prime-ministers of India! Because of her efforts and commitment, Jitwarpur has been developed to a large extent. She died in 2005.

\subsection{Baua Devi}

Baua Devi is from Jitwarpur in Mithila district, Bihar. She brought the wall 
paintings on to paper in 1966. She was born to a Brahmin family and married off at 12 and during that year there had been a famine. To supplement her family's income the women in the region started selling their artworks using new media. She was encouraged by artist Bhaskar Kulkarni who helped her to showcase Madhubani artworks at New Delhi's Craft Museum. She was awarded a Padma Shri in 2017. Figure 11 shows the artist, Baua Devi showcasing her work.

\subsection{Ganga Devi}

Born into a Kayastha family in 1928 in Mithila, Bihar, she was a Madhubani painter who took the art outside India, specialising in kachni, line drawings. She participated in the Festival of India in the US. She got the National award for Crafts and the Padma Shri in 1984.

\subsection{Mahasundari Devi}

Mahasundari Devi was from Ranti village in Madhubani, Bihar. She learned the art of Madhubani from her aunt at an early age. She broke social norms like the 'purdah' and became an active artist in 1961 and founded a co-operative society Mithila Hastashilp Kalakar Audyogki Sahyog Samiti. She got conferred with many awards like the National Award in 1982, Tulasi Samman by the Madhya Pradesh Govt in 1995 and the Padma Shri in 2011. Her art included clay, paper mache, sujani and sikki (grass arts). She died in 2013. Figure 12 is an image of Mahasundari Devi at work.

\subsection{Other Artists}

Other artists active in Madhubani painting are Yamuna Devi, Shanti Devi, Chano Devi, Mudrika Devi, Phoolmaya Devi, Bindeshwari Devi, Chandrakala Devi,

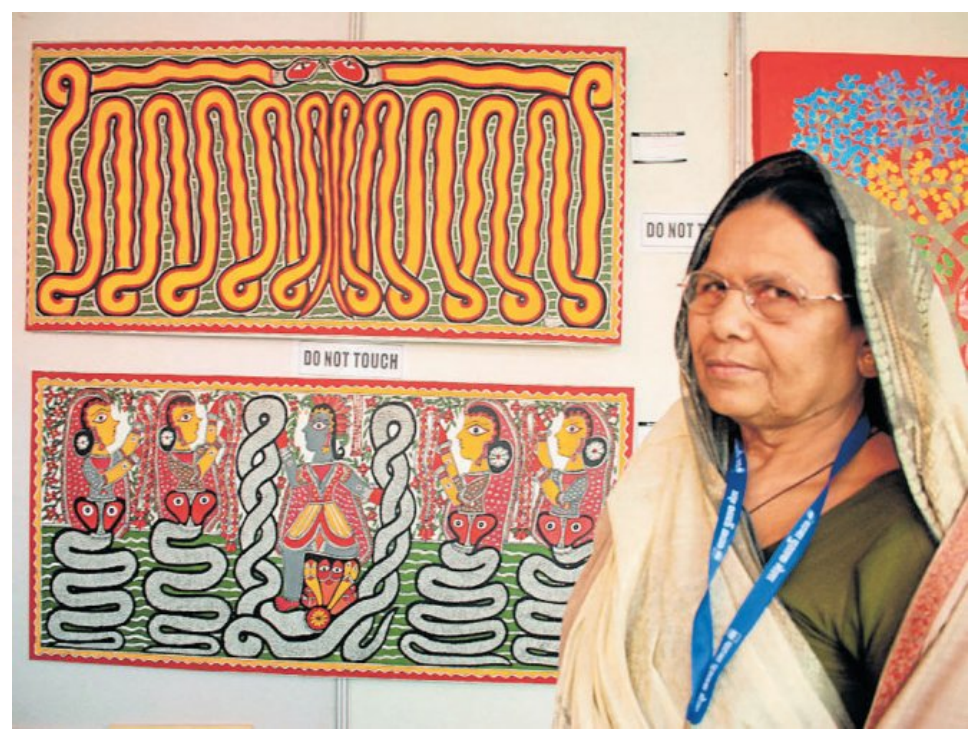

Figure 11. Baua Devi, artist (Source: https://www.deccanherald.com/content/597118/jitwarpur-bihar-scores-hattrick-padma.h tml (newspaper image) (accessed 12.03.2020)). 


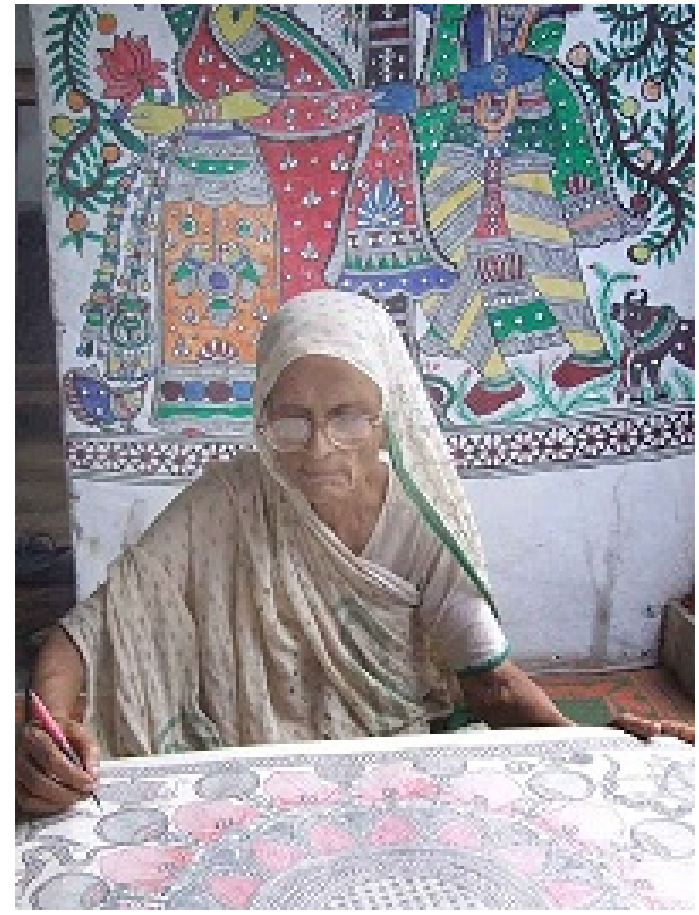

Figure 12. Mahasundari Devi, artist. Mahasundari devi, CC BY-SA 3.0 https://creativecommons.org/licenses/by-sa/3.0, via Wikimedia Commons (accessed 12.03.2020).

Shashikala Devi, Leela Devi, Godavari Dutta, Chandrabhushan, Ambika Devi and Manisha Jha who have got National awards. Jagannath Jha is another well known artist. Also Dulari Devi, Karpuri Dev, Mahalaxmi and Radha Kumari have made their mark as Madhubani artists.

\subsection{Bharti Dayal}

Bharti Dayal is a contemporary artist from Samastipur, Darbhanga district of Bihar, working in this field from 1984. She is actively propagating the art on media like acrylic and canvas. She has got recognition of the art as a fine art worldwide and has won many awards and held an exhibition at the Museum of Sacred Art, Belgium. She guided other women artists. She paints with natural and vegetable based colours (Dayal, 2016). She combines traditional art and modern topics of the day. She has won the National Award for Excellence in Crafts in 2006. Her painting in Figure 13 "Bitiya" means daughter, in Hndi language, highlighting the girl child.

The image in Figure 14 depicts Kaliyamardana from Lord Krishna's life. As per legend Kaliya was the name of a poisonous naga living in the Yamuna river. The water around the naga bubbled and boiled with poison and no living thing could venture around it. A sole kadamba tree grew on its bank. Kaliya was living there because he had been chased away from Ramanakadwipa by Garuda, enemy of all serpents. Kaliya chose Vrindavan because Garuda has been cursed by a sage of Vrinadvan that he would meet his death if he ever came to Vrindavan. 


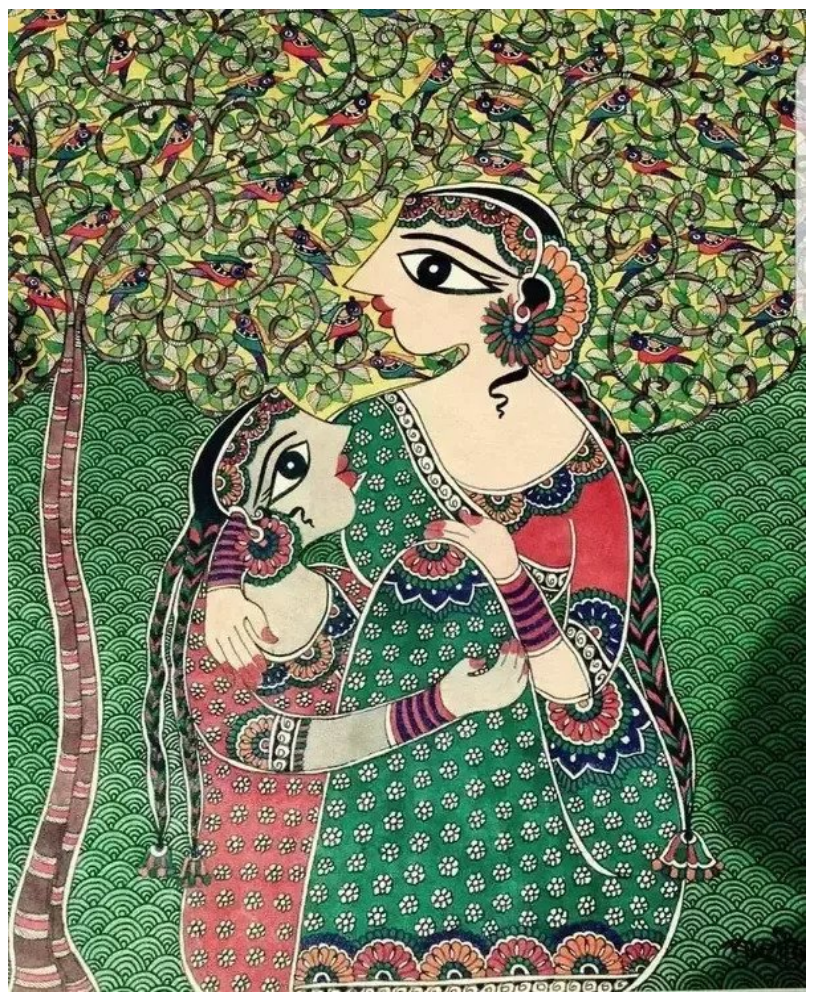

Figure 13. Bitiya, painting by Bharti Dayal. Bharti Dayal, CC BY-SA 4.0, https://creativecommons.org/licenses/by-sa/4.0, via Wikimedia Commons (accessed 12.03.2020).

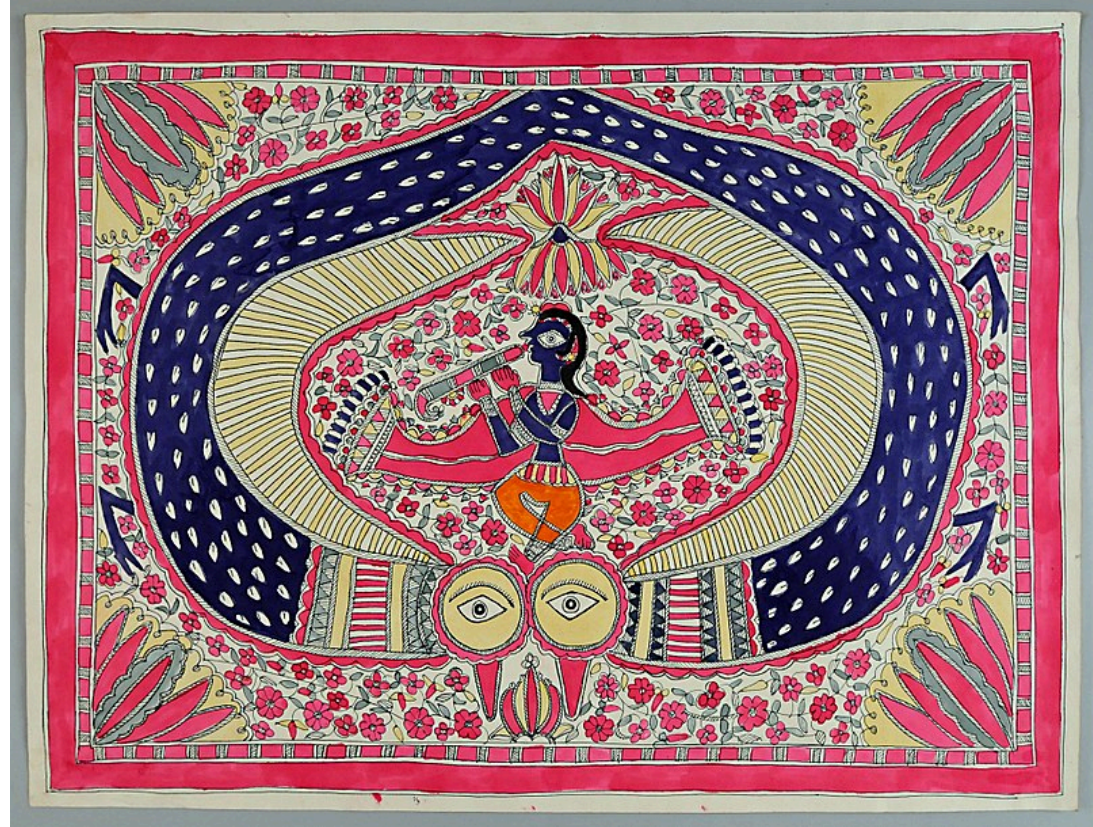

Figure 14. Kaliyamardana, Madhubani painting (Source: Asia and Pacific Museum in Warsaw by Mudrika Devi).

Once Lord Krishna was playing with other cowherds next to the Yamuna. Their ball fell into the river. Krishna who had climbed the tree tried to retrieve it by 
jumping into the river. Kaliya rose up with his hoods and wrapped himself around Krishna's body. A great fight ensued; Krishna grew large to assume the weight of the universe and danced on Kaliya's hoods. The naga began to die, but his wives came and prayed to Lord Krishna to release him. The naga surrendered and Krishna set him free to go back to Ramanakadwipa. Legend has it that he went to the netherworld and stayed there.

A painting with a depiction of a scene from the "Ramayana" epic is seen in Figure 15. This is the kidnapping of Sita, the wife of Rama, by the demon Ravenna. Ravana is sitting on the backs of horses. Made in the bharni style (coloured), derived from the tradition of the Brahmins and Kayasthas.

A jail in New Delhi has Madhubani paintings on its walls as shown in Figure 16, which could probably set a trend for other institutions to encourage this practice.

Jitwarpur has produced artists like Siban Paswan, Siva Lal Das, Rekha Das, Satya Narayan Koru and Joy Narayan Lal Das in the field, which has Governmental support with 38 centres in Bihar, 21 in North Bihar alone and assistance given for marketing of the finished pieces as well (Das, 2013).

Modern $21^{\text {st }}$ century homes are always looking for something "different" or unique to enliven living spaces. Figure 17 depicts a wall livened up using this art form. Madhubani art is thus helping in this regard with both retail outlets selling the paintings across India and with the advent of shopping through Internet portals, it is being sold online which goes a long way in sustaining this ancient art-form by providing livelihood to the artists and from it getting lost in the vicissitudes of time.

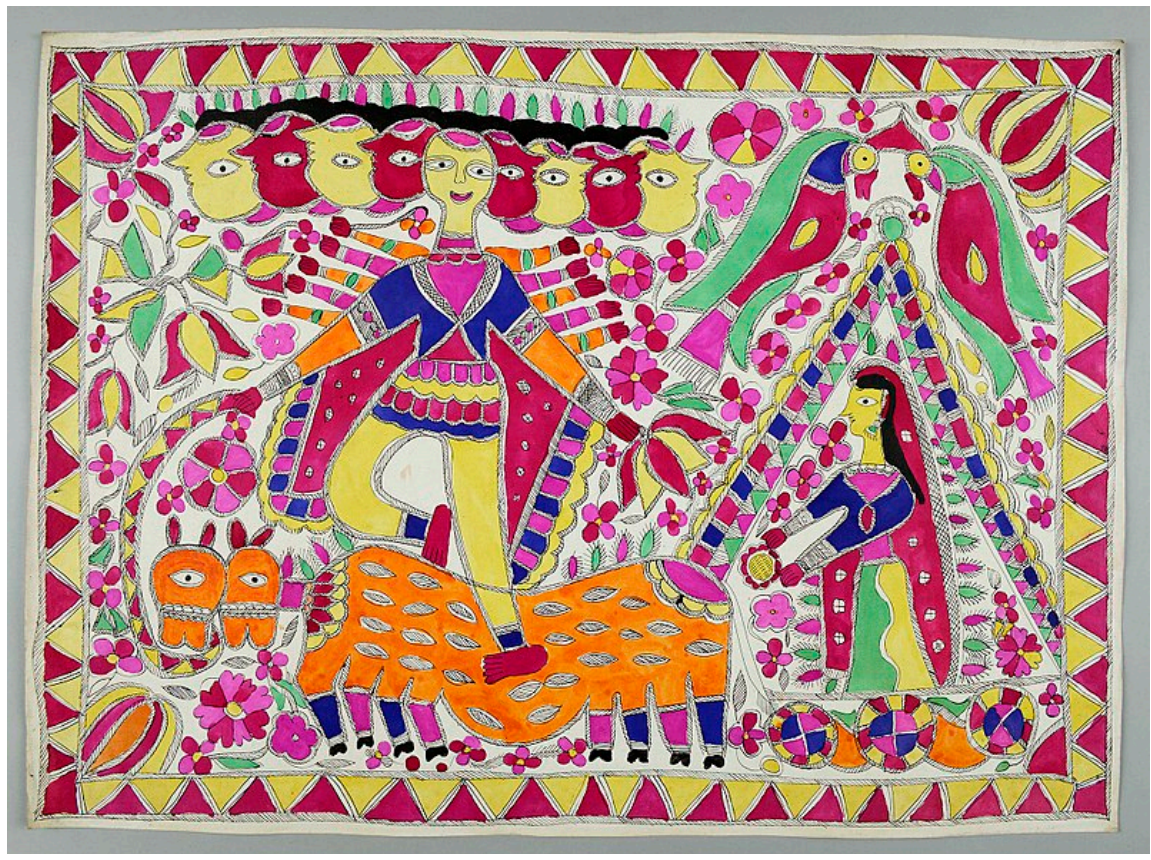

Figure 15. Scene from the epic Ramayana, Madhubani painting (Source: Asia and Pacific Museum). 


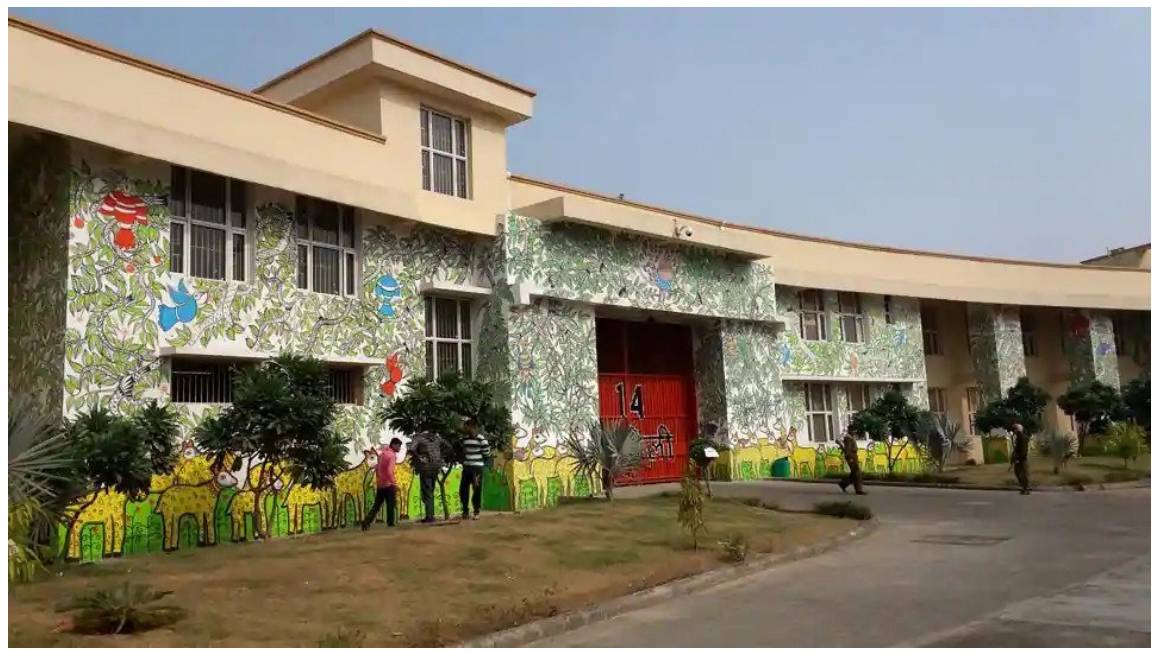

Figure 16. Madhubani paintings on Mandoli sub-jail, New Delhi (Source: https://www.hindustantimes.com/delhi-news/murals-graffitti-madhubani-paintings-mando $\underline{\text { li-sets-art-free-on-delhi-s-jail-walls/story-EULW9ZWsjeYmkt7GvvOUUJ.html (newspaper }}$ image) (accessed 12.03.2020)).

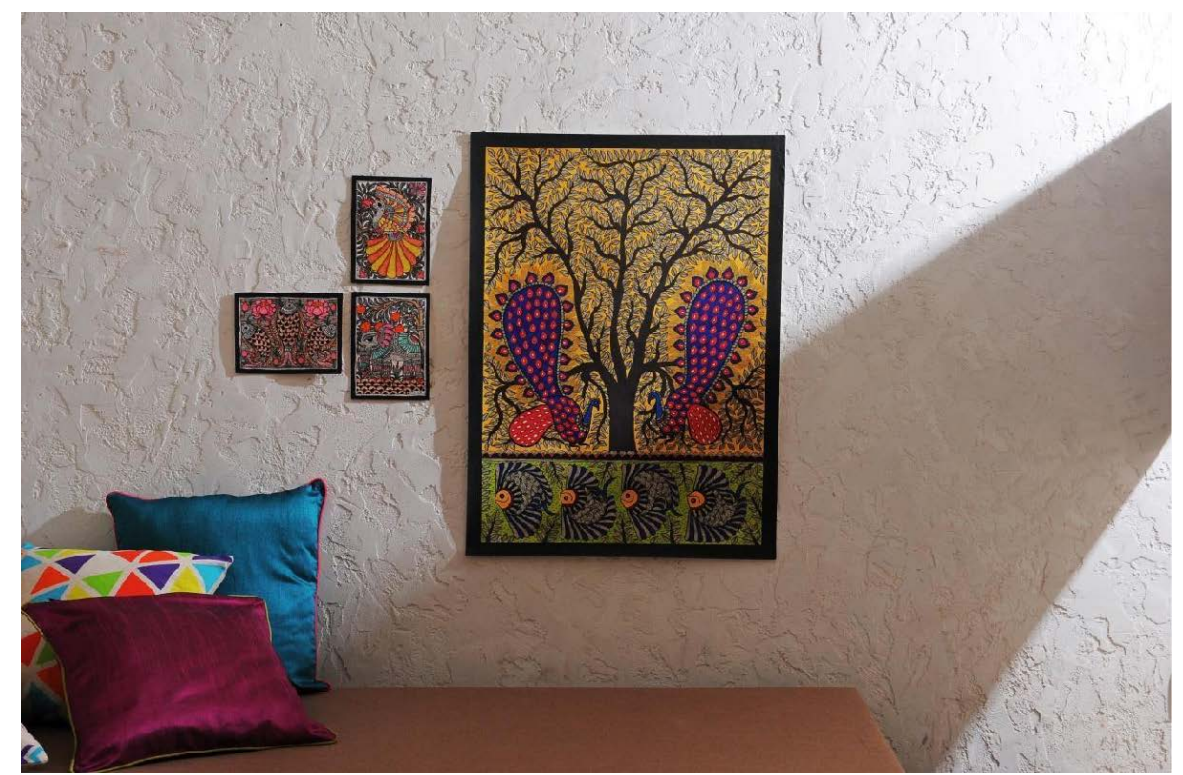

Figure 17. Madhubani panels, contemporary drawing room, $21^{\text {st }}$ century (Source: jaypore.com with kind permission from CEO Shri Puneet Chawla).

\section{Conclusion: The Journey Continues}

This ancient art which began as murals on walls and floors of village homes in North Bihar continues its journey with both the traditional motifs and the modern idioms juxtaposing each other as can be seen on walls, public spaces and in outlets selling the craft. As seen in the article, the traditional families will continue to make the paintings during ceremonies and the art form will adorn the rooms of newly-weds, the kohabara. On the other hand in addition to narrating a mythological event from the strong repertoire of Indian legends or depicting daily life and rituals, or depicting social themes and motifs of animals and birds, 
the paintings will find a place in public spaces and elite drawing rooms thus ensuring a market for survival. Also online e-commerce sites have begun selling the craft which augurs well to expand the market. So as we move on to the $21^{\text {st }}$ century there will be more of Madhubani on different surfaces including apparel, tableware, upholstery and home décor. Innovations will find a way to keep the art thriving and fresh in the eyes of the discerning global buyer who may also be an art enthusiast. The painting practice provides income and empowers women who also have a goal to empower others, which makes them aware of their rights and gives them confidence to deal with other social issues.

\section{Conflicts of Interest}

The author declares no conflicts of interest regarding the publication of this paper.

\section{References}

Anand, M. R. (1984). Madhubani Painting. New Delhi: Publications Division.

Archer, W. G. (1949). Maithil Painting, Marg: A Magazine of Architecture and Art, Vol. 3, No. 3. Bombay: Marg Publications.

Das, N. (2013). Madhubani Paintings-Its Existence and Possibility. International Journal of Scientific and Research Publications, 3, 1-7.

Dayal, B. (2016). Madhubani Art. New Delhi: Niyogi Books.

Jain, J. (1997). Ganga Devi-Tradition and Expression in Mithila Painting. Ahmedabad: Mapin Publishing.

Neel, R. (2010). From Folk Art to Fine Art: Changing Paradigms in the Historiography of Maithil Painting. Journal of Art Historiography, No. 2, 1-20.

Thakur, U. (1981). Madhubani Painting. New Delhi: Abhinav Publications.

Tiwari, S. (2018). Madhubani Painting-The Empowerment of Heritage. Journal of Current Science, 19, 1-7. 